Vol. 2, No. 2, pp. 122-125, (June 2021)

DOI: 10.21608/AUJES.2021.71844.1017

Aswan University Journal of Environmental Studies (AUJES)

Online ISSN: 2735-4237, Print ISSN: 2735-4229

Journal homepage: https://aujes.journals.ekb.eg/

E-mail: AUJES@aswu.edu.eg

Original research

\title{
Sensory Parameters of Minced Meat in Aswan City
}

Nady Khairy $^{{ }^{*} \text {, Mohamed Karmi }}{ }^{1}$, Mohamed Abdelfattah Maky ${ }^{2}$

${ }^{l}$ Department of Food Hygiene and Control, Faculty of Veterinary Medicine, Aswan University, Aswan, Egypt

${ }^{2}$ Department of Food Hygiene and Control, Faculty of Veterinary Medicine, South Valley University, Qena, Egypt

Received: $10 / 4 / 2021$

Accepted: 2/5/2021

(C) Unit of Environmental Studies and Development, Aswan University

\begin{abstract}
:
Meat is an important foodstuff and one of the most expensive components of human nutrition; therefore 30 minced meat samples were collected from Aswan city shops for evaluation of sensory quality parameters. Seven characteristics grades were given to panelists from1. Dislike extremely to 7. Like extremely. Panelists were considered the above points for evaluation of appearance, texture, consistency, odor, and overall acceptance of the meat samples. The results shown that the mean values of appearance, texture, consistency, odor, and overall acceptance were $18.1 \% \pm 6.84 \%, 22.4 \% \pm 8.46 \%, 19.85 \% \pm 7.5 \%, 19.64 \% \pm 7.42 \%$, and $20.19 \% \pm 7.63 \%$, respectively. All tested sensory values were non-significant. The findings indicated that the sensory evaluation of minced meat samples varied among different locations where a variation in preparation method was observed as well as the type of meat cut included.
\end{abstract}

Keywords: minced meat, sensory analysis, organoleptic evaluation

\section{1- INTRODUCTION}

Minced meat marks a valuable role in the diet in Egypt because of its nutritive value, as a basis of protein, holding great biological value, an outstanding source of several nutrients; mainly protein, fat, B-vitamin, Iron, Zinc, Vitamin A, essential and non-essential amino-acid necessary to build, maintain and improve body tissues (Williams, 2007). Minced beef products remove the morphological features of muscle, causing it complicated to identify one type of muscle from another. Because after crushing and mixing, the source of meat varieties is easy to be undistinguished in the mixture due to the change of meat texture, color, and appearance, or even flavor (Manjula et al. 2009). For this purpose, meat substitution with undefined species, usually of cheaper quality, is the most prevalent form of economic corruption in minced meat production, establishing a fraudulent act that could possess economic and health impacts. Therefore, the present study evaluates the sensory quality parameters of minced meat in Aswan city.

Corresponding author*: E-mail address: Nadyvet82@yahoo.com 


\section{2- MATERIALS AND METHODS}

\subsection{Preparation of samples}

30 different minced meat samples of different companies were randomly collected from different markets in various regions in Aswan city, Egypt. All samples were wrapped, identified next brought in a cooler box to the Central Lab; Faculty of Veterinary Medicine; Aswan University for their analysis (Harrigan, 1998).

\section{2- Sensory analyses}

About $250 \mathrm{~g}$ of each sample will cut with the same size, shape, and uniform thickness by using a meat slicing machine (Delonghi, Mod.SL360; China) labeled until evaluated for sensory values. The samples will serve to panel members for organoleptic evaluation of appearance, texture, consistency, odour, and overall acceptability of the meat samples according to Gracey (1986); Miller (1994) and Marriot (1995). Seven characteristics grades were given to panelists from1. Dislike extremely to 7 . Like extremely. Panelists were considered the above points for organoleptic evaluation of minced meat specimens. Every evaluation practiced in individual compartments in daylight conditions.

\section{2- Statistical Report}

Means and standard error were calculated among samples using One-way Analysis of Variance (ANOVA) was done concerning significant differences between the samples using the Microsoft Office Excel 2007 and GraphPad InStat 3 for Windows software. A statistically significant difference was estimated at $\mathrm{p}<0.05$.

\section{RESULTS AND DISCUSSION}

Regarding the results of the sensory evaluation of minced meat samples that detailed in the Fig. (1), it was evident that the main values for appearance, texture, consistency, odor, and overall acceptance were $18.1 \% \pm 6.84 \%, 22.4 \% \pm 8.46 \%, 19.85 \% \pm 7.5 \%, 19.64 \% \pm 7.42 \%$ and $20.19 \% \pm 7.63 \%$, respectively. Based on ANOVA results, it could be noticed that there were no significant difference were found between appearance, texture, consistency, odor, or overall acceptability $(\mathrm{P} \leq 0.05)$ of different samples.

Additionally, Levy and Hanna (1994) stated that the most potent visual cue for the consumer is the amount of visible fat considering buying minced beef at retail showing that first impression reinforces their observation of how good it is. In minced meat product, a color variation is resulting from the drying method so must have had colorants added to become bright color and appeal to the consumers. In past studies from Australia, Canada, Egypt, Saudi Arabia, Turkey, the United Kingdom, and the USA, A multiplicity of meat adulteration especially in processed meat products was registered (CCWA, 1999; MAFF, 1999; Odumeru, 2003; Ayaz et al.2006; El Sangary and Ibrahim, 2006; Türkyllmaz and Irmak, 2008; Abd El-Nasseret et al. 2010; D'Amato et al. 2013). It is unspoken that meat substitution is a key tool in lessening the production costing of meat and meat products. This fact could reasonably interpret the hazard to public health.

The conclusions from the studies of Hsieh et al. (1995) and Ayaz et al. (2006) showed that meat species replacement occurs extra frequently in processed meat commodities, for example in the ground, comminuted, cured, and value-added products. The reason for this may lie in the fact that deliberate substitution with cheaper species is more difficult to discover in such 
products by visual observation than it is in fresh, intact meat. the origins of constituents can be easily disguised in the meat mixture during processing methods often lead to variations in the appearance, color, texture, and even flavor of meat products (Flores-Munguia et al., 2000).

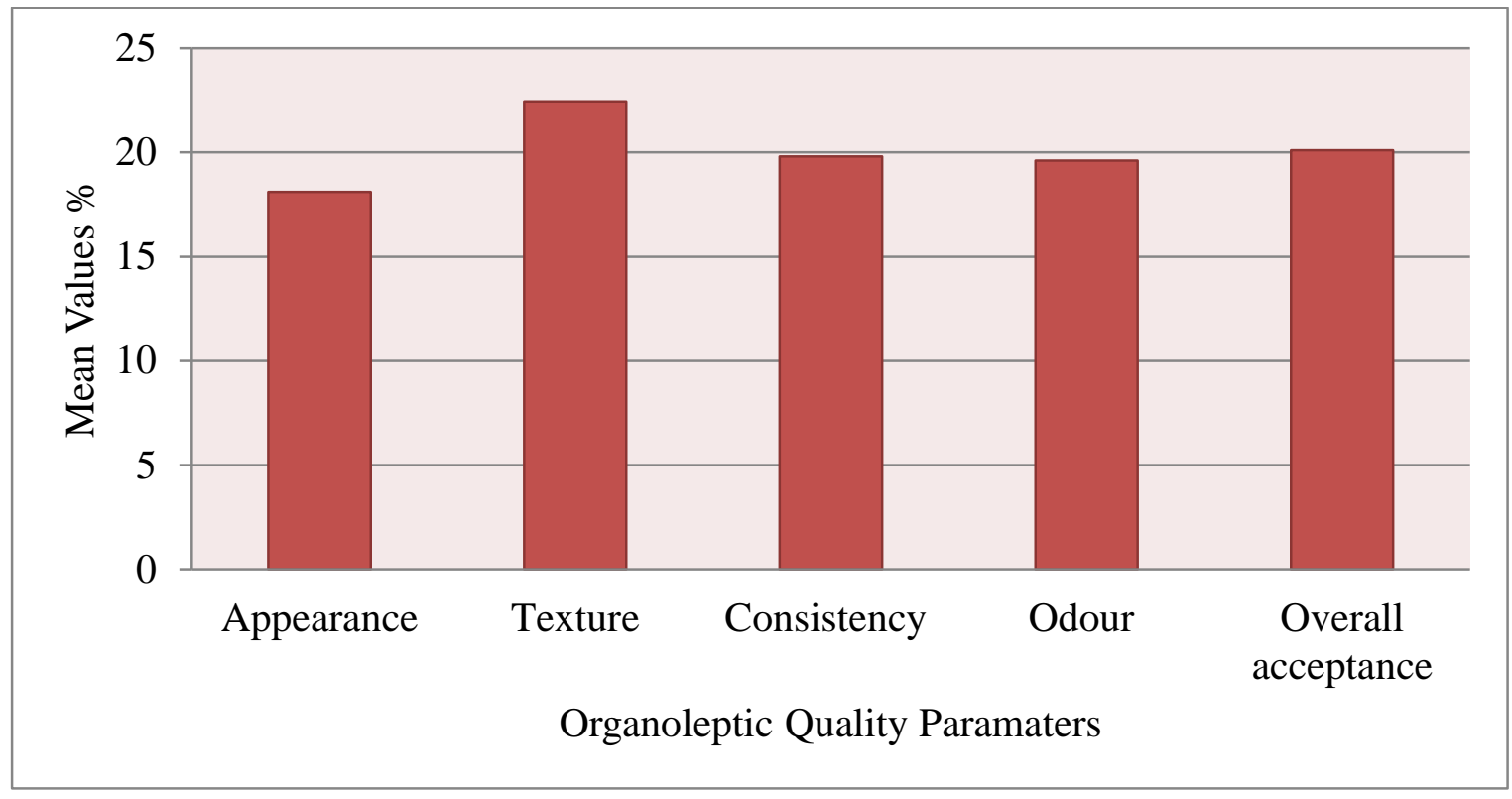

Fig. 1: Mean values of Organoleptic Evaluation of Minced Meat Samples

\section{Conclusion}

The sensory characteristics of minced meat are one of the main issues affecting consumers' satisfaction. Sensory analysis conducted by panelists is the most relevant means to illustrate differences between the treatments as seen by humans. The findings indicated that the sensory evaluation of minced meat samples varied among different locations where a variation in preparation method was observed as well as the type of meat cut included. Available data of the sensory evaluation of minced meat also assist consumers to make healthier and satisfying choices for maintaining a healthy lifestyle. Lastly, this finding gives a better and clearer picture of sensory evaluation of minced meat available in Aswan city, Egypt.

\section{References}

Abd El-Nasser, M.; Labieb, H. and Doaa, M. Abd El-Aziz (2010). Identificationof meat species in some meat products in Assiut city. Ass. Univ. Bull. Environ. Res. 13 (2).

Ayaz, Y.; Ayaz, N. and Erol, I. (2006). Detection of species in meat and meat products using enzyme-linked immunosorbent assay. Journal of Muscle Foods, 17:214- 220.

CCWA (1999). Chemistry Center of Western Australia,Western Australian Food Monitoring Program, Available from Department of Health of Western Australia.

D'Amato, M.; Alechine, E.; Cloete1, K.; Davison, S. and Corach, D. (2013). Where is the game? Wild meat products authentication in South Africa: a case study. Investigative Genetics.; 4:6. 
El-Sangary, R. and Gabrail, G. (2006). Differentiation between different animal meats using species specific Polymerase Chain Reaction technique. 12th Sci. Cong. Fac. Vet.Med., Assiut Univ. Egypt.

Flores-Munguia, M. E.; Bermudez-Almada, M. C., and V azquez-Moreno, L. (2000). A research note: detection of adulteration in processed traditional meat products. Journal of Muscle Foods, 11, 319-325.

Gracey, J.F. (1986). Meat hygiene. $8^{\text {th }}$ Edn. The English long Book Sic and Baillier: Tindall.

Harrigan, W. (1998). Laboratory methods in food microbiology. 3rded. Academic Press, San Diego, Calif. pp. 43-70.

Hsieh, Y.-H.P.; Woodward, B.B. and Ho, S.H. (1995). Detection of species substitution in raw and cooked meats using immunoassays. J Food Prot 58:555-9.

Levy, S. and Haanna, M. (1994). Consumer quality audit summary. DesMonines, I.A. National Pork Producers Council.

MAFF, U.K. (1999): Meat Speciation Survey. No.176. Available from Food Standards.Agency

Manjula, T., W. Indarjit and S. Amarjit, (2009). Impact of health education package on knowledge and practices of women regarding food adulteration. Nursing Midwifery Res. J., 5(1): 1-9.

Marriot, N. (1995). Score sheet for pane test. Personal communication. 1995.

Miller, R.K. (1994). Quality characteristics. In: Kinsmam KM, KotulaAW,Breidenstein BC, editors. Muscle Foods. Chapman and Hall: New York. 1994.

Odumeru, J. (2003). Field application of protein fingerprinting technology for assessment of meat adulteration incidence in meat processing plants and retail stores in Ontario. Ontario Ministry of Agriculture and Food. Enhanced Food Quality and Safety Research Program.

Türkyılmaz, Ö. and Irmak, H. (2008). Determination of species in meat and meat products with ELISA technique). J. Bornova Vet. Cont. Res. Inst., 30(44), 27-31.

Williams, P.G., (2007). Nutritional composition of red meat, Nutrition \& Dietetics. The official Journal of the Dietitians Association of Aus 